\title{
The Effect of the Application of the Nature of Science (NOS) Learning Model on Student Learning Outcomes
}

\author{
Nursalam Matondang ${ }^{1, *)}$, I. Kusumawati ${ }^{2}$, Eka Murdani ${ }^{3}$ \\ STKIP Singkawang, Singkawang, Indonesia \\ nursalammtdng@gmail.com ${ }^{1}$, intankusumawati@gmail.com ${ }^{2}$, ekamurdani@gmail.com ${ }^{3}$ \\ ${ }^{*}$ Corresponding author
}

Keywords:

Nature of Science, Learning

Outcomes, Static Fluid

\begin{abstract}
This study aimed to show the effect of implementing the Nature of Science (NOS) learning model on student learning outcomes. This type of research was a quantitative study with a sampling technique that is purposive sampling and a research design in the form of an experimental class and a control class. Based on statistical analysis using the SPSS application, it was identified that the data presented is normally distributed so that the data analysis in the next step used the parametric statistical T-test where it was found that sig 0.000 is smaller than 0.05, so HO is rejected and Ha is accepted, which means that there was a significant effect on the learning outcomes of the experimental class students before and after the NOS learning model was applied to the Static Fluid material. The data collection instrument in this study was in the form of pre-test and post-test question sheets. After the data were analyzed using the effect size equation and it was found that the NOS learning model in the experimental class and control class had a difference of 1.681 with high criteria.
\end{abstract}

\section{INTRODUCTION}

Learning Science is an ideal way to gain competence, knowledge, skills, and develop mastery of concepts related to everyday life, Science is related to how to systematically find out about nature and the environment. Science is not only a collection of knowledge in the form of facts, concepts, or principles but also a process of discovery and that is related to the environment (Suastra, 2009). Science learning must also be able to provide direct experience to students in developing their ability to explore and understand the natural surroundings scientifically (Murdani \& Sumarli, 2019).

Based on SMP Negeri 19 Singkawang, it was found that student learning outcomes were still low. One of the physics materials with low learning outcomes is the Static Fluid material. Static Fluid is one of the physics concepts studied by junior high school students, where this material has a conceptual relationship with other materials and tends to be applied to the environment and everyday life. This is reinforced by the findings in the form of a recap of the daily test scores on Static Fluid in class VIII students of the 2015/2016 academic year, which is less than 50, even though the Minimum Completeness Criteria (KKM) in physics subjects at the school is 65. 
This is because learning is still teacher-centered, students tend to only accept what is conveyed by the teacher without being oriented towards the school environment and the natural surroundings as a study of learning. In addition, when learning takes place, many students tend to do actions that make the classroom atmosphere not conducive, so that conditions like this greatly affect student learning outcomes on the material being conveyed by the teacher.

The solution to overcome this is by providing learning that can improve student learning outcomes, one of the alternative learning models in overcoming this is the Nature of Science (NOS) learning model. The NOS-based learning model stages not only involve students in doing science but are involved in discussion and reflection. The NOS-based learning model requires students to be involved in science and to reflect on what they learn about scientific activities so that NOS learning becomes more effective (Sudirgayasa, 2014).

NOS-oriented learning includes three things, namely (1) Ontology, namely knowledge as a field of science that studies articulation, sociology, and history; (2) Epistemology, namely knowledge as a way to gain understanding, insight, and wisdom; and (3) Axiology, namely knowledge that focuses more on the benefits of this knowledge for the community and the environment. So, NOS is an intermediary for students to reveal and understand natural realities (Dewi, 2013).

Learning outcomes are the abilities obtained by individuals after the learning process takes place, which can provide changes in behavior, both knowledge, understanding, attitudes, and skills of students so that they become better than before (Suprijono, 2012). The cognitive domain Concerning Cognitive Learning Objectives stated the following: (1) remembering, (2) understanding, (3) applying, (4) analyze, (5) apply, and (6) evaluate (Anderson et al., 2010). Table 1 is the syntax for the NOS learning model (Dewi, 2013).

Table 1

The Syntax of the NOS Learning Model

Learning Phase Learning Activities

Phase 1: Background Reading

Students read books to encourage a sense of curiosity

Phase 2: Case Study Discussions and dig deeper into related concepts

Phase 3: Inquiry Lessons

The teacher is doing a demonstration

The teacher asks questions about demonstrations that have been carried out to cause cognitive conflict and student curiosity to stimulate students to formulate initial assumptions (hypotheses) before carrying out investigative activities

Phase 4: Inquiry Labs Students conduct experiments, observe, infer, classify, explain two-variable relationships, discuss and make conclusions

Phase 5: Historical Studies

The teacher asks questions so that students explain the concept so that it is more detailed, accurate, and can be linked to new concepts

Phase 6: Multiple Assessments The assessment used is oriented towards student learning outcomes. The test used is in the form of a description item.

Based on this background, it is known that the NOS learning model can provide input in improving student learning outcomes. 
METHOD

This research is a type of quantitative research with a sampling technique that is purposive sampling. In this study, the number of samples taken was two classes from three classes. One class gets learning using the Nature of Science (NOS) learning model (experimental class) and the other class gets learning using a conventional learning model (control class).

The data collection instrument was in the form of a pre-test post-test sheet, which aims to determine student learning outcomes in Static Fluid material. The sheet consists of 12 learning outcome questions given to students with 4 indicators of learning outcomes. The question sheets were given before and after the learning model was applied (treatment) by applying the NOS learning model. After the data is obtained then analyzed using the effect size equation with the help of the SPSS application, as for the effect size equation as shown in Equation (1).

$$
\mathrm{ES}=\frac{\bar{Y}_{E}-\bar{Y}_{C}}{S_{C}}
$$

Information: $E S=$ Effect Size; $\bar{Y}_{E}=$ Average score of the experimental group; $\bar{Y}_{C}=$ The average score of the control group; $S_{C}=$ Standard deviation of control group. The effect size criteria (Nurhayati, 2014) can be seen in Table 2.

Table 2

\begin{tabular}{cc}
\multicolumn{2}{c}{ Effect Size } \\
\hline Score & Criteria \\
\hline $\mathrm{ES} \leq 0,2$ & Low \\
$0,2<\mathrm{ES} \leq 0,8$ & Moderate \\
$\mathrm{ES}>0,8$ & High \\
\hline
\end{tabular}

\section{RESULTS AND DISCUSSION}

Based on the results of the analysis that has been carried out, the student's learning outcomes of the static fluid material given to the experimental class and control class before and after the implementation of the Nature of Science (NOS) learning model were obtained, namely experiencing differences between the experimental and control classes. The difference in learning outcomes referred to in this study is the difference in learning outcomes before and after the NOS learning model is applied which is analyzed by the normality test and the T-test assisted by the SPSS application.

Based on the results of statistical analysis using SPSS, it was identified that the data presented were normally distributed so that the data analysis in the next step could use the two-sample T-test parametric statistics paired. The results of the T-test show that the significance of 0.000 is less than 0.05 , so Ho is rejected and Ha is accepted, which means that there is an effect of the application of the NOS learning model on student learning outcomes on Static Fluid material in class VIII. The hypothesis for the T-test in this study is as follows. HO: There is no significant effect on the application of the NOS learning model on student learning outcomes in class VIII grade Static Fluid. Ha: There is a significant effect on the application of the NOS learning model on student learning outcomes in the Class VIII Static Fluid material. To find out how much influence the NOS learning model has on student learning outcomes seen from the effect size criteria. The result of the effect size found is 1.681 which is included in the high criteria.

\section{CONCLUSION AND SUGGESTION}

Based on the results of the analysis, it was concluded that based on the T-test that sig 0.000 is smaller 
than 0.05 , Ho is rejected and $\mathrm{Ha}$ is accepted, meaning that there was a significant effect on student learning outcomes in the experimental class before and after the NOS learning model is applied to the Static Fluid material. Based on the results of the analysis, it could be seen that the effect size of student learning outcomes between the experimental class and the control class after the NOS learning model is applied is 1.681 which is included in the high criteria.

Based on the discussion and research results as well as the conclusions that have been obtained, there are several suggestions from researchers for the improvement of further similar research. Some of these suggestions are that the teacher should apply the NOS learning model in schools as an alternative to improving student learning outcomes because the NOS learning model has been proven to affect student learning outcomes, the NOS learning model should be used for material that can be related to the real world of students, in other words, it can be used practicum.

\section{REFERENCES}

Anderson, L, W. \& Krathwohl, D, R. (2010). Kerangka Landasan untuk Pembelajaran, Pengajaran dan Assessment. Jakarta: Pustaka Pelajar.

Dewi. (2013). Pengaruh Model Pembelajaran Berorientasi Nature of Science terhadap Hasil Belajar IPA Siswa Kelas IV di SD Gugus V Kabupaten Buleleng. Universitas Pendidikan Ganesha Singaraja, Indonesia.

Murdani, E., \& Sumarli, S. (2019, February). Student learning by experiment method for analyzing the dynamic electrical circuit and its application in daily life. In Journal of Physics: Conference Series, 1153(1), 012119. IOP Publishing.

Nurhayati, Fadilah. \& Mutmainnah, S. (2014). Penerapan Metode Demonstrasi Berbantuan Media Animasi Software Phet terhadap Hasil Belajar Siswa dalam Materi Listrik Dinamis Kelas X Madrasah Aliyah Negeri 1 Pontianak. Jurnal Pendidikan Fisika dan Aplikasinya, 2(2).

Suastra, W. (2009). Pembelajaran Sains Terkini Mendekatkan Siswa dengan Lingkungan Alamiah dan Sosial Budayanya. Jurnal Ilmiah, Program Study IPA Universitas Muhammadiyah Utara, $3(1)$.

Sudirgayasa. (2014). Pengaruh Model Pembelajaran Berbasis Nature of Science (NOS) terhadap Kemampuan Aplikasi Konsep Biologi dan Pemahaman NOS Siswa dalam Pembelajaran Biologi di SMA Negeri 1 Marga. Program Studi Pendidikan IPA, Program Pascasarjana Universitas Pendidikan Ganesha Singaraja, Indonesia

Suprijono, Agus. (2012). Cooperative Learning Teori dan Aplikasi PAIKEM. Yogyakarta: Pustaka Belajar. 